\title{
PENGARUH TEKNOLOGI DALAM DUNIA PENDIDIKAN
}

\author{
Ana Maritsa \\ Universitas Ahmad Dahlan \\ Jl. Ringroad Selatan, Daerah Istimewa Yogyakarta \\ Ana1900031368@webmail.uad.ac.id \\ Unik Hanifah Salsabila \\ Universitas Ahmad dahlan \\ Jl. Ringroad Selatan, Daerah istimewa Yogyakarta \\ unik.salsabila@pai.uad.ac.id \\ Muhammad Wafiq \\ Universitas Ahmad dahlan \\ Jl. Ringroad Selatan, Daerah istimewa Yogyakarta \\ Muhammad1900031158@webmail.uad.ac.id \\ Putri Rahma Anindya \\ Universitas Ahmad dahlan \\ Jl. Ringroad Selatan, Daerah istimewa Yogyakarta \\ putri1900031212@webmail.uad.ac.id \\ Muhammad Azhar Ma'shum \\ Universitas Ahmad Dahlan \\ Jl. Ringroad Selatan, Daerah istimewa Yogyakarta \\ Muhammad1900031169@webmail.uad.ac.id
}

DOI: 10.46781/al-mutharahah.v18i2.303

\begin{abstract}
Influence of Technology for Education. As time goes by technology in the world of education has experienced various developments, where everything has used technology to facilitate all its work, including in the world of education as now the increasing number of vocational high schools being built is proof that educational technology in Indonesia is increasingly advanced because vocational schools use tools and media in carrying out learning that is done at school. Technology becomes a supporting tool used in education to make it easier for teachers to teach students with the results to be achieved. In times like today we often encounter the use of technology in the implementation of learning carried out by an educator to teach or students or students to learn. However, in the development of modern technology, it can also not only have a positive impact on education, but also have a negative impact on behavioral changes carried out by students which can damage norms, educational rules, and morals in social life.
\end{abstract}

Keywords: Influence; Technology; Education

\begin{abstract}
Abstrak
Pengaruh Teknologi bagi Pendidikan. Seiring berjalannya waktu teknologi dalam dunia pendidikan mengalami berbagai perkembangan, dimana segala hal sudah memanfaatkan teknologi untuk mempermudah segala pekerjaannya, termasuk dalam dunia Pendidikan seperti sekarang semakin banyaknya sekolah menengah kejuruan yang di bangun itu menjadi
\end{abstract}


bukti bahwa teknologi pendidikan yang ada di Indonesia semakin lama semakin maju, karena sekolah kejuruan mengunakan alat dan media dalam melakukan pembelajaran yang di lakukan disekolah. Teknologi menjadi sebuah alat pendukung yang digunakan dalam pendidikan untuk mempermudah guru dalam mengajar peserta didik dengan hasil yang ingin dicapai. Di masa seperti saat ini sering kita temui adanya penggunaan teknologi dalam pelaksanaan pembelajaran yang dilakukan oleh seorang pendidik untuk mengajar atau pelajar atau mahasiswa untuk belajar. Namun dalam perkembangan teknologi yang modern ini juga bisa saja tidak hanya berdampak positif bagi pendidikan, tetapi juga membawa dampak negatif pada perubahan perilaku yang di lakukan oleh peserta didik yang bisa merusak norma, aturan pendidikan, dan moral dalam kehidupan sosial.

Kata Kunci: Pengaruh; Teknologi; Pendidikan

\section{A. Pendahuluan}

Memasuki zaman sekarang dengan adanya kemajuan teknologi yang mengglobal telah mempengaruhi di berbagai aspek kehidupan baik di bidang politik, ekonomi, kebudayaan, seni dan bahkan di bidang pendidikan. Kemajuan teknologi pada perkembangan zaman ini merupakan sesuatu yang tidak dapat kita hindari dalam kehidupan, karena kemajuan teknologi berjalan sesuai dengan kemajuan ilmu pengetahuan. Dalam bidang Pendidikan teknologi mempunyai pengaruh penting dalam ilmu pengetahuan dimana dalam ilmu pengetahuan para peserta didik di ajarkan tentang gejala dan fakta alam dan dengan adanya teknologi ini manusia megunakan teknologi untuk menerapkan ilmu pengetahuan tersebut ${ }^{1}$. Teknologi membantu manusia untuk menciptakan sebuah inovasi yang dapat membantu keseharian manusia sehari-hari dan mempermudah sebuah pekerjaan yang sangat menguras tenaga.

Teknologi adalah sesuatu yang bisa membantu seluruh manusia di seluruh dunia untuk membantu menjadi sarana untuk menjalankan kegiatan harian yang di Kerjakan oleh manusia dalam bekerja maupun dalam pendidikan. Teknologi juga termasuk dalam sesuatu bidang ilmu pengetahuan untuk mempelajari suatu sistem yang terdapat dalam komputer ataupun laptop yang dan membuat suatu alat atau aplikasi yang terpasang dalam suatu jaringan untuk membantu atau memudahkan manusia dalam kegiatan setiap hari. Dalam perkembangan zaman yang lebih modern maka teknologi juga semakin canggih dan lebih maju seperti lebih banyaknya media pendukung pekerja dan siswa atau mahasiswa dalam mengerjakan tugas. Seperti hal nya sekarang yang tiba-tiba munculnya sebuah virus dari Cina yang membuat lemah nya perekonomian dan pendidikan, oleh sebab itu pada waktu ini teknologi sangat di butuhkan untuk semua orang karena kebanyakan aktivitas yang di lakukan oleh semua pekerja maupun murid atau mahasiswa dilakukan secara daring atau online di rumah, banyak media yang di kelola oleh pihak mana pun seperti meet, zoom, clasroom dan yang lainya. Adanya teknologi yang baru ini memudahkan semua pekerja dan pelajar memudahkan mereka berkeja dan sekolah, namun ada beberapa masalah yang ada dalam mengunakan media tersebut.

Adanya peningkatan penciptaan teknologi padasaat ini, semua pihak yang ada di dalam dunia pendidikan ini harus dapat mengimbangi dan mengikuti kemajuan teknologi yang ada. Dapat kita lihat bahwa dierpengaruh lingkungan sekitar kita teknologi sangat didukung dengan tersedianya jaringan internet yang dapat berpengaruh pada perkembangan lainnya, terutama dalam lingkup dunia pendidikan. Dalam pendidikan, internet di manfaatkan sebagai pendukung dalam media pembelajaran ${ }^{2}$. Dunia pendidikan perlu meningkatkan kemajuan sekolah dan pendidikan dengan mengadakan inovasi yang positif. Sekolah diharapkan tidak ketinggalan kabar mengenai canggihnya teknologi dengan menyediakan

\footnotetext{
${ }^{1}$ Dian Rahadian, "Teknologi Informasi Dan Komunikasi (TIK) Dan Kompetensi Teknologi Pembelajaran Untuk Pengajaran Yang Berkualitas,” Jurnal Teknologi Pendidikan Dan Pembelajaran 2, no. 1 (2017): $234-54$.

${ }^{2}$ Nala Nafilata Fadilah and Punaji Setyosari, "MOTIVASI BELAJAR MAHASISWA TEKNOLOGI" 4, no. 1 (2021): 90-97, https://doi.org/10.17977/um038v4i12021p090.
} 
perangkat elektronik yang mendukung proses pembelajaran. Sarana dan prasarana yang baik dan lengkap akan menjadikan kegiatan pembelajaran berjalan dengan efektif dan efisien ${ }^{3}$.

Pendidikan adalah suatu pembelajaran atau mempelajari pengetahuan, keterampilan yang di lakukan atau di kerjakan oleh manusia untuk mengetahui hal-hal yang akan di kerjakan di dalam dunia pekerjaan. Pendidikan di mulai sejak dini yaitu TPA ( tempat penitipan anak) sampai jenjang kuliah atau universitas untuk jenjang paling tinggi. Di Indonesia pendidikan terbagi menjadi beberapa bagian, ada Negeri, swasta dan muhammadiyah. Untuk negeri semua siswa atau mahasiwa bisa belajar di sekolah tersebut, semua agama boleh bersekolah di sekolah negeri sedangkan untuk swasta kebanyakan Sekolah nya berbasis Islam dan dan pembelajaran nya tentang agama dan sekolah muhammadiyah mengfokuskan untuk dari keluarga muhammadiyah namun juga menerima siswa yang luar muhammadiyah. Sebenarnya tidak ada yang beda dari sekolah-sekolah tersebut, karena pada hakikatnya sekolah untuk menuntut ilmu dan menanamkan pendidikan yang ada menurut sekolah tersebut. Pendidikan juga bekal untuk mencari pekerjaan yang akan di ambil oleh peserta didik maupun mahasiswa, karena pada setiap pendidikan memiliki jurusan masing-masing tergantung sekolah ataupun universitas. Pendidikan juga bisa sebagai olak ukur kcerdasan seseorang, karena mereka yang memiliki pendidikan akan di pandang menjadi seorang yang berilmu dan bisa menjadi kepercayaan suatu organisasi maupun kelompok.

\section{B. Metode Penelitian}

Penelitian ini mengunakan penelitian kepustakaan yaitu mencari sumber penelitian dengan cara mengumpulkan dari beberapa literatur yang bersumber dari jurnal, buku dan sumber-sumber lainnya, agar lebih mudah dalam melakukan penelitian mengenai Pengaruh Teknologi dalam Dunia Pendidikan. Pada penelitian teknik yang di gunakan untuk pengumpulan data yaitu dengan cara mencari materi yang berkaitan dengan pembahasan pada aartikel ini, baik secara digital maupun manual. Setelah melakukan referensi, kemudian menganalisis data-data yang telah terkumpul dengan mendisplay, meredukasi, dan merekontruksi sehingga menjadi sebuah konsep yang baru, dengan menggunakan analisis isi yang lebih mengutamakan intertekstualitas.

\section{Pembahasan}

\section{Makna Teknologi Pendidikan}

Dalam ermasalahan yang sering terjadi pada dunia Pendidikan yang ada di Indonesia adalah lemahnya proses kegiatan pembelajaran yang di lakukan di dalam kelas, dalam hal ini proses pembelajaran yang ada hanya teori yang di lakukan lingkungan kelas dan pembelajaran ini bertujuan untuk mengarahkan kemampuan peserta didik untuk memahami materi. Padahal dalam teori tersebut kurangnya materi penerapan kehidupan sehari-hari. Dalam pembelajaran kehadiran seorang pendiidk memiliki potensi tinggi dalam mengembangkan potensi yang di miliki oleh murid dan kreativitas, namun peran penting teknologi Pendidikan yang ada saat ini sangat berguna untuk pembelajaran dari tingkat bawah sampai tingkat atas seperti media

\footnotetext{
${ }^{3}$ Hariza Noor Perdani and Raekha Azka, "Teknologi Dan Pembelajaran Matematika Generasi Milenial," $\begin{array}{llllll}\text { Proseding } & \text { Sendika } & 5, & \text { no. } & 1 & \text { (2019): }\end{array}$ https://www.researchgate.net/publication/334986462_Teknologi_dan_Pembelajaran_Matematika_Generasi_Mil enial.
} 
pembelajaran yang dapat di fungsikan sebagai media untuk belajar yang mengasyikan, media juga membantu untuk mencari wawasan yang lebih lengkap ${ }^{4}$.

Teknologi pendidikan dapat di artikan sebagai sebuah kajian atau praktek untuk pelajar membantu dalam proses belajar mengajar di sekolah bisa berupa proses membuat suatu pengajaran yang membutuhkan sebuah proses yang mengunakan teknologi yang ada dan memadai untuk membuat suatu konsep pembelajaran. Dalam teknologi pendidikan yang perlu di gunakan adalah sistem yang di perlukan dalam membuat proses dalam mengembangkan kebutuhan atau kinerja manusia dalam setiap hari, dalam proses nya teknologi pendidkan membutuhkan beberapa komponen seperti komponen dan peralatan yang di gunakan dalam mengolah dan membuat analisis data dan memecahakan sebuah masalah yang ada. Di dalam pembelajaran alat-alat yang di gunakan dalam teknologi pendidikan dapa juga merubah posisi guru dalam mengajar karena dalam pembelajaran tersebut guru mengharapkan peserta didik dapat mengunakan teknologi yang sekarang sudah ada dan juga teknologi yang cangih untuk memperesentasikan hasil belajar mereka dengan alat-alat tersebut bisa berupa media ataupun yang lain. Peran guru juga tetap di perlukan untuk tetap mengajar di dalam kelas karena fungsi dari teknologi itu sendiri untuk memudahkan pembelajaran bukan untuk mengambil peran guru untuk seutuhnya ${ }^{5}$.

Pemanfaatan teknologi pembelajaran merupakan salah satu sarana penyiapan tenaga kerja dimasa depan, karena dalam aspek ini dipandang sebagai suatu bidang yang memiliki kepentingan mengenai persekolahan. Kepala sekolah dan dinas pendidikan perlu memperhatikan teknologi pendidikan terkait dengan lingkungan pendidikan yang bersifat formal,oleh karena itu teknologi pendidikan yang di gunakan saat ini mulai berkembang sebagai pendidikan yang mengajarkan teori dan praktik dimana proses, sumber dan sistem pada manusia dapat di rancang, di kembangkan, dimanfaatkan, dikelola dan dinilai. Ilmu, informasi yang perlu di kuasai tidaklah sedikit, namun sangatlah banyak dan tanpa batas ${ }^{6}$. Perkembangan teknologi pendidikan ini sangat di tentukan oleh peningkatan kebutuhan, dipengaruhi perkembangan ilmu teknologi sebagai kreatifitas produk manusia. Komunikasi dan informasi dikatakan sebagai pengaruh perkembangan teknologi.

Teknologi dan pendidikan dalam kehidupan adalah sebuah bagian yang tidak terpisahkan antara kehidupan manusia dari zaman dahulu sampai akhir zaman. Pendidikan dan teknologi ini selalu mengapami perkembangan seiring dengan perkembangan manusia di muka bumi. Pendidikan merupakan karakter pembentuk kepribadian yang sangatlah penting, ketika perkembangan zaman dalam pendidikan pasti selalu mengaalami perubahan yang lebih baik dan kuat dari sebelumnya ${ }^{7}$.

\section{Peran Teknologi Pendidikan}

Teknologi ini berperan sebagai kendaraan dalam penyampaian pengajaran. Teknologi dalam pendidikan dijadikan sebagai peranta untuk tercapainya tujuan pembelajaran. Peserta didik yang dapat memanfaatkan teknologi dalam pendidikan dengan baik untuk menambah ilmu pengetahuan ${ }^{8}$. Teknologi dalam menunjang Pendidikan dapat di harapkan untuk membantu para pelajar dan pendidik dalam melaksanakan kegiatan belajar mengajar di

${ }^{4}$ N. M. Dwijayani, "Development of Circle Learning Media to Improve Student Learning Outcomes," Journal of Physics: Conference Series 1321, no. 2 (2019): 171-87, https://doi.org/10.1088/17426596/1321/2/022099.

5 Nasruddin Hasibuan, "Pengembangan Pendidikan Islam Dengan Implikasi Teknologi Pendidikan," FITRAH:Jurnal Kajian Ilmu-Ilmu Keislaman 1, no. 2 (2016): 189, https://doi.org/10.24952/fitrah.v1i2.313.

${ }^{6}$ Andi Kristanto, “Aplikasi Teknologi Pendidikan Di Sekolah,” Jurnal Teknologi Pendidikan 4 (2016): $13-16$.

${ }^{7}$ Rizka Ariani, “Analisis Landasan Ilmu Pengetahuan Dan Teknologi Pendidikan Dalam Pengembangan Multimedia Interaktif Program Pasca Sarjana Pendidikan Fisika , FMIPA Universitas Negeri Padang," Jurnal Penelitian Pembelajaran Fisika 5, no. 2 (2019): 157.

8 Sudarsri Lestari, "Peran Teknologi Dalam Pendidikan Di Era Globalisasi," Edureligia; Jurnal Pendidikan Agama Islam 2, no. 2 (2018): 94-100, https://doi.org/10.33650/edureligia.v2i2.459. 
sekolah jadi guru dapat terbantu dalam menerangkan atau mengasihmteri kepada muridnya tanpa harus lelah untuk mengecek hasil pelatihan yang di berikan kepada murid tersebut. Pada zaman saat ini perkembangan teknologi informasi pada zaman milenial atau di zaman era globalisasi yang lebih modern ini peranan teknologi informasi sangat di butuhkan untuk beberapa hal yan gmenyangkut dibidang Pendidikan sekolah maupun universitas. Tuntutan global menuntut dunia pendidikan untuk selalu memperbarui teknologi dan senantiasa menyesuaikan untuk menyesuaikan sekolah dengan perkembangan teknologi informasi terhadap usaha dalam peningkatan mutu pendidikan, terutama penyesuaian penggunaannya bagi dunia pendidikan khususnya dalam proses pembelajaran. Oleh karena itu, teknologi pendidikan sangat membantu dalam pembelrian pelatihan pendidikan kepada guru atau mahasiswa supaya ketika terjun ke perkerjaan ia bisa bekerja secara profesional, dan dapat menggunakan fasilitas belajar yang ada dalam perkembangan teknologi yang ada ${ }^{9}$.

Teknologi informasi tidak hanya di gunakan di sekolah aja bisa juga di gunakan untuk pekerjaan seperti sekolah SMK yang dimana di sekolah tersebut mereka di ajarka untuk bekerja langsung sesuai jurusanya dengan dibantu teknoogi yang baru seperti kejuruan otomotif maka sekolah menyediakan alat atau teknologi untuk menunjang kegiatan tersebut jadi setelah lulus para peserta didik langusng bisa mengoperasikan alat-alat yang ada di bengkel. Teknologi informasi juga dapat membantu perekonomian masyarakat seperti sekarang sudah bayak aplikasi yang membantu untuk berpergian atau memesan makanan hanya melalui handphone seperti go jek, grab dan shopee food, dengan aplikasi tersebut dapat membanu driver mencari nafkah dan menambah penghasilan bagi toko atau yang menjadi tujuan pemesanan dari customer. Yang terakhir di dalam dunia pertanian teknologi sangat berpngaruh dalam pertanian seperti alat pembajak sawah yang dulu pertama di lakukan mengunakan kerbau sekarang seiring teknologi semakin canggih untuk membajak sawah mengunakan traktor yang menggunakan mesin jadi mempermudah petani untuk membajak sawah dan untuk mengasih pestisida di tanaman yang di tanam saat ini ada alat bantu yang mempermudah yaitu meggunkan drone atau pesawat tanpa awak yang di kendalikan menggunakan remot control yang bisa di lakukan dari jarak jauh jadi menguragi tenaga petani. Industrial teknologi yang saat ini ada bisa menyebabkan terjadinya sebuah perubahan yang sangat mendasar yang di rasakan dalam aspek sosial dan ekonomi ${ }^{10}$.

Pembelajaran adalah salah satu bentuk proses dalam mendalami ilmu yang di ajarkan oleh seorang guru atau ahli dalam bidangnya, dalam proses tersebut membutuhkan beberapa komponen yang bisa membantu dalam melaksanakan proses pembelajaran tersebut, di butuhkan media atau alat yang memiliki teknologi yang bisa menyeimbang bidang yang di ajarkan. Dalam hal ini interaksi yang di lakukan oleh guru dan peserta didiknya dapat menimbulkan suatu pengetahuan yang tinggi. Proses pembelajaran merupakan suatu hal yang positif karena para peserta didik belajar dari yang sama sekali tidak rau menjadi tau tentang pembelajaran tersebut, seperti teknologi orang yang awam akan teknologi jika di bimbing dan mempelajari tentang teknologi maka lama kelamaan orang itu akan menjadi paham tentang dunia teknologi, begitu pula teknologi sangat berpengaruh terhadap pembelajaraan karena dalam pembelajaran kita pendidik juga memerlukan bantuan teknologi untuk mengasih materi kapada peserta didik dan bisa di bilang teknologi mengantikan peran guru di dalam kelas

${ }^{9}$ M.Pd2 Dr. Yuberti, "Peran Teknologi Pendidikan Dalam Perspektif Islam," Jurnal Pemikiran Islam STAIN Jurai Siwo Metro Lampung ISSN 3, no. 7 (2015): 59-78.

10 Muhammad Taufiq, "Pengaruh Teknologi Informasi Dalam Keprofesian Dan Implikasinya Dalam Dunia Pendidikan," NATURALISTIC : Jurnal Kajian Penelitian Pendidikan Dan Pembelajaran 1, no. 2 (2017): 176-85, https://doi.org/10.35568/naturalistic.v1i2.8. 
namun tidak sepenuhnya guru juga masih di butuhkan untuk menerangkan materi yang tidak paham secata langsung dan mengontrol para peserta didik di dalam kelas ${ }^{11}$.

\section{Pengaruh Positif Teknologi Terhadap Dunia Pendidikan}

Dengan adanya teknologi tentunya membuat pendidikan ini menjadi sangat mudah. Semua orang akan lebih mudah dalam belajar apapun tanpa adanya halangan karna jauh. Sekolah dan perguruan tinggipun mudah untuk mencari informasi yang bisa dilakukan di rumah dan dapat menjangkau di beberapa daerah, siswa yang mengikuti pembelajaran daring dengan mudah. Teknologi untuk meningkatkan kualitas mutu pendidikan, perangkat dalam pendidikan yang interaktif merupakan jalan untuk meninngkatkan pendidikan dengan menginteraksikan teknologi ke dalam kelas. Teknologi dikatakan sebagai pusat sumber daya yang bagus sebagai penunnjang dalam proses pengajaran dan bembelajaran. Hal ini tertulis dalam Permendiknas No 41 Tahun 2007 tentang Kompetensi Lulusan Standar Isi, maka prinsip pembelajaran yang digunakan pada point ke-13 yang berbunyi "Pemanfaatan teknologi informasi dan komunikasi untuk meningkatkan efisiensi dan efektifitas pembelajara" $"$. Teknologi sebagai penetapan memilih strategi pembelajaran, bahan dan peralatan media yang di gunakan guna unntuk meningkatkan suasana pembelajaran.

Penerapan teknologi bermanfaat bagi pendidikan yaitu:

a. Munculnya media masa, sebagai sumber ilmu pengetahuan dan pusatnya pendidikan khusunya median elektronik. Contohnya yaitu jaringan internet, Lab komputer .

b. Dampaknya yaitu guru tidak hanya sebagai acuan sumber ilmu pengetahuan, sehingga siswa tidak hanya terpusat pada guru dan informasi belajar yang diberikan oleh guru saja,namun juga dapat mengakses materi pembelajaran melalui internet, guru memiliki peran sebagai pengajar dan pembimbing, jadi setiap siswa di bimbing dalam dalam belajar untuk mengarahkan dan memantau proses pendidikan, supaya siswa ini tidak salah jalan dalam menggunakan Media Informasi dalam belajar di sekolah.

c. Adanya metode baru yang dapat memprmudah dalam proses belajar siswa di sekolah. Dengan teknologi maka terciptalah metode yang bersifat menarik perhatian siswa dalam belajar, dan memudahkan memahami materi.

d. Pembelajaran dapat dilaksanakan secara daring, contohnya yaitu dengan menggunakan aplikasi zoom, google meet, dan bisa menggunakan jasa pos internet.

e. Adanya sistem pengelolaan data hasil penilaian yang menggunakan pemanfaatan teknologi .pada saat belum berkembangnya teknologi manusia melakukan sebuah penelitian, analisis data itu harus dilaksanakan secara langsung dan terjun ke lapangan dan dihitunng secara manual, namun dengan adnya teknologi pada saat ini semua tugas dapat dikerjakan melalui teknologi, tanpa membutuhhkan waktu yang lama dan hasilnya lebih akurat. Contoh teknologinya yaitu laptop atau komputer yang dapat mengelola data dengan memanfaatkan program yang ada di laptop atau komputer.

f. Terpenuhinya fasilitas pendidikan secara cepat. Misalnya dalam pembuatan soal itu perlu membuat soal sesuai banyak siswa yang ada di sekolah, maka dari itu dengan adanya mesin foto copy yang dapat menggandakan copyan dalam waktu yang cepat. Dengan adanya perkembangan teknologi semua ini dapat dilakukan dengan menyingkat waktu.

11 Sudi Suryadi, "Peranan Perkembangan Teknologi Informasi Dan Komunikasi Dalam Kegiatan Pembelajaran Dan Perkembangan Dunia Pendidikan," Jurnal Informatika 3, no. 3 (2019): 9-19, https://doi.org/10.36987/informatika.v3i3.219.

12 Destiana, "Pengaruh Teknologi Informasi Berbasis Android (SMARTPHONE) Dalam Pendidikan Industri," Prosiding Seminar Nasional Pendidikan Program PAasca Sarjana Universitas PGRI Palembang, 2019, 190-97. 
Proses pembelajaran terdapat beberapa manfaat yang diperoleh dari teknologi yaitu:

a. Pembelajaran ini akan lebih menarik dan efektif.

b. Digunakan untuk menjelaskan sesuatu yang komplek secara jelas dan mudah di pahami.

c. Dapat mempercepat proses yang lama menjadi cepat.

d. Menghadirkan peristiwa yang langka, serta banyak penemuan-penemuan yang baru.

e. Menunjukan peristiwa yang tidak disangka-sangka oleh manusia .

\section{Pengaruh Negatif Teknologi Terhadap Dunia Pendidikan}

Teknologi bagi pendidikan selain berpengaruh positif, namun ada juga pengaruh negatifnya. Dalam dunia pendidikan ketrampilan bicara dan komunikasi ini merupakan salah satu ketrampilan yang harus dimiliki. Ketika pembelajaran melalui internet maka komunikasi akan berkurang, oleh sebab itu mereka lebih cenderung berinteraksi dengan teknologi.Di dalam dunia Pendidikan pasti ada beberapa masalah yang bisa terjadi yang di lakukan oleh peserta didik maupun guru, masalah yang di maksud adalah pengaruh negative yang mungkin bisa saja terjadi karena seperti yang kita semua tau bahwa teknologi zaman sekarang di era milenial ini sangat cangih jadi semua apapun yang ada di dunia teknologi bisa di akses dan ini menjadi suatu permasalahan yang ada. Dalam beberapa contoh berikut ini menjadi pengaruh negatif yang di lakukan oleh peserta didik maupun guru.

a. Seringnya siswa atau mahasiswa yang sering mengakses sesuatu di internet maka dapat dikhawatirkan mereka jika mereka memanfaatkan apa yang ada di teknologi informasi namun tidak dengan optimal melainkan mereka mengunakannya untuk hal yang lain atau mereka malah mengakses informasi yang mengandung hal yang tidak baik, seperti pornografi dan game online. Hal ini yang menjadi kekhawatiran oleh guru maupun orang tua siswa tersebut, karena dalam hal itu bisa merusak pikiran mereka dan membuat pendidikanya terganggu.

b. Bagi Peserta didik mereka dapat terkena information overload, yakni mereka dapat mengakses semua yang ada dan mereka dapat menemukan informasi yang mereka cari secara terus menurus seperti membuka hal-hal yang berbau pornografi yang dapat menimbulkan pada diri mereka sebuah kecanduan untuk megakses pornografi tersebut dan juga game online yang membuat mereka rela menghabiskan uang hanya untuk game tersebut dan yang jadi masalah adalah kesehatan mata peserta didik tersebut karena terlalu sering menatap layer monitor dan juga dapat menganggu kegiatan belajar mereka danitu sangat merugikan bagi mereka dan bahkan mereka bisa meningalkan kewajiban wajib mereka yaitu sholat karena terlalu asyik bermain game online.

c. Banyak dari siswa atau mahasiswa yang menjadi pecandu dunia maya atau internet, hal ini yang menebabkan adanya perilaku apatis terhadap sesuatu hal yang baru, maka dari itu dalam penggunaan internet harus ada sebuah benteng atau filter dalam melakukan aksesnya. Selain itu adanya perhatian orang tua atau adanya pengawasan orang tua adalah peran penting dalam menanamkan pola pikir dalam kehidupan seorang anak.

d. Dalam teknologi terdapat Tindakan kriminal (Cyber Crime). Namun tidak hanya di dunia teknologi aja, namun di dalam dunia pendidikan hal ini juga dapat terjadi dan bisa menjadi maslah yang serius di dunia Pendidikan, misal ada siswa atau mahasiswa yang mencuri dokumen atau aset yang bersifat rahasia atau penting yang berisi tentang sebuah tatanan yang ada di pendidikan yang sesungguhnya asset itu dirahasiakan seperti dokumen yang mengenai ujian akhir, nilai, dan presensi yang di lakukan dengan media yang dapat di akses melalui internet ${ }^{13}$.

${ }^{13}$ Yohannes Marryono Jamun, "Dampak Teknologi Terhadap Pendidikan," Pendidikan Dan Kebudayaan Missio, no. 10 (2018): 48-52. 
Seiring bertumbuhnya seorang remaja maka makin banyak hal yang ingin di ketahui oleh remaja dan juga mencari jati dirinya dan mereka mencoba untuk mengikuti pola pikir dan tingkah laku seperti orang dewasa, dan mereka para remaja mulai mengikuti apa yang orang dewasa kerjakan setiap hari melalui internet mereka bisa mencari hal-hal apa saja yang biasa di kerjakan oleh orang dewasa seperti membeli narkoba atau menonton video pornografi, seebnarnya seja remaja mereka sudah mulai menyalahgunakan teknologi seperti mengajak tawuran melalui media sosial, saling ejek antar sekolah dan yang lainya. Dan yang berperan unntuk mencegah pengaruh negatif adalah peran dari para orang tua dan juga guru untuk di sekolahan dengan mengurangi pengunaan handphone atau teknologi yang lainya setiap hari dan jangan menyarankan anak untuk keluar tengah malam karena itu adalah sumber dari pengaruh negatif tersebut ${ }^{14}$.

\section{Simpulan}

Berkembangnya ilmu pengetahuan dan teknologi yang terjadi secara terus menerus yang menimbulkan beberapa pengaruh bagi lingkungannya. Adanya teknologi segala aspek ikut terpengaruhi misalnya ekonomi, sosial polotik bahkan pendidikan. Berdasarkan materi yang kita bahas yaitu pengaruh dalam bidang pendidikan. Pengaruh ini bukan hanya berpengaruh positif tetapi juga berpengaruh negatif. Pengaruh positif teknologi dalam pendidikan diantaranya yaitu memudahkan setiap peserta didik dalam mencari informasi, ilmu pengetahuan, dan meluasnya wawasan bagi peserta didik. Sedangkan pengaruh negatifnya yaitu ada beberapa anak yang menyalahgunakan kegunaan dari teknologi tersebut. Misalnya memanfaatkan teknologi tersebut untuk bermain game yang berlebihan sehingga mengurangi kefokusan dalam belajar yang dapat menyebabkan turunnya prestasi anak. Dengan adanya pengaruh positif dan negatif tersebut, maka kita sebagai pengguna harus profesional dalam pemanfaatan teknologi dengan baik sehingga perkembangan teknologi yang terjadi ini dapat berjalan dengan baik. Teknologi juga dapat mempermudah pekerjaan, oleh karena itu manfatkanlah teknologi dengan sebaik mungkin

${ }^{14}$ Lita Kurnia and Ahmad Edwar, "Pengaruh Negatif Di Era Teknologi Informasi Dan Komunikasi Pada Remaja (Perspektif Pendidikan Islam)," Kordinat: Jurnal Komunikasi Antar Perguruan Tinggi Agama Islam 20, no. 2 (2021): 291-308, https://doi.org/10.15408/kordinat.v20i2.22183. 


\section{DAFTAR PUSTAKA}

Ariani, Rizka. "Analisis Landasan Ilmu Pengetahuan Dan Teknologi Pendidikan Dalam Pengembangan Multimedia Interaktif Program Pasca Sarjana Pendidikan Fisika, FMIPA Universitas Negeri Padang." Jurnal Penelitian Pembelajaran Fisika 5, no. 2 (2019): 157.

Destiana. "Pengaruh Teknologi Informasi Berbasis Android (SMARTPHONE) Dalam Pendidikan Industri." Prosiding Seminar Nasional Pendidikan Program PAasca Sarjana Universitas PGRI Palembang, 2019, 190-97.

Dr. Yuberti, M.Pd2. "Peran Teknologi Pendidikan Dalam Perspektif Islam." Jurnal Pemikiran Islam STAIN Jurai Siwo Metro Lampung ISSN 3, no. 7 (2015): 59-78.

Dwijayani, N. M. "Development of Circle Learning Media to Improve Student Learning Outcomes." Journal of Physics: Conference Series 1321, no. 2 (2019): 171-87. https://doi.org/10.1088/1742-6596/1321/2/022099.

Fadilah, Nala Nafilata, and Punaji Setyosari. "MOTIVASI BELAJAR MAHASISWA TEKNOLOGI" 4, no. 1 (2021): 90-97. https://doi.org/10.17977/um038v4i12021p090.

Hasibuan, Nasruddin. "Pengembangan Pendidikan Islam Dengan Implikasi Teknologi Pendidikan.” FITRAH:Jurnal Kajian Ilmu-Ilmu Keislaman 1, no. 2 (2016): 189. https://doi.org/10.24952/fitrah.v1i2.313.

Kristanto, Andi. “Aplikasi Teknologi Pendidikan Di Sekolah.” Jurnal Teknologi Pendidikan 4 (2016): 13-16.

Kurnia, Lita, and Ahmad Edwar. "Pengaruh Negatif Di Era Teknologi Informasi Dan Komunikasi Pada Remaja (Perspektif Pendidikan Islam)." Kordinat: Jurnal Komunikasi Antar Perguruan Tinggi Agama Islam 20, no. 2 (2021): 291-308. https://doi.org/10.15408/kordinat.v20i2.22183.

Lestari, Sudarsri. "Peran Teknologi Dalam Pendidikan Di Era Globalisasi." Edureligia; Jurnal Pendidikan Agama Islam 2, no. 2 (2018): 94-100. https://doi.org/10.33650/edureligia.v2i2.459.

Marryono Jamun, Yohannes. "Dampak Teknologi Terhadap Pendidikan." Pendidikan Dan Kebudayaan Missio, no. 10 (2018): 48-52.

Perdani, Hariza Noor, and Raekha Azka. "Teknologi Dan Pembelajaran Matematika Generasi Milenial." Proseding Sendika 5, no. 1 (2019): 508-14. https://www.researchgate.net/publication/334986462_Teknologi_dan_Pembelajaran_Mat ematika_Generasi_Milenial.

Rahadian, Dian. "Teknologi Informasi Dan Komunikasi (TIK) Dan Kompetensi Teknologi Pembelajaran Untuk Pengajaran Yang Berkualitas." Jurnal Teknologi Pendidikan Dan Pembelajaran 2, no. 1 (2017): 234-54.

Suryadi, Sudi. "Peranan Perkembangan Teknologi Informasi Dan Komunikasi Dalam Kegiatan Pembelajaran Dan Perkembangan Dunia Pendidikan." Jurnal Informatika 3, no. 3 (2019): 9-19. https://doi.org/10.36987/informatika.v3i3.219. 
Taufiq, Muhammad. "Pengaruh Teknologi Informasi Dalam Keprofesian Dan Implikasinya Dalam Dunia Pendidikan.” NATURALISTIC : Jurnal Kajian Penelitian Pendidikan Dan Pembelajaran 1, no. 2 (2017): 176-85. https://doi.org/10.35568/naturalistic.v1i2.8. 